\title{
Production of Methanethiol from Methionine by Brevibacterium linens CNRZ 918
}

\author{
By M. FERCHICHI, * D. HEMME, MICHÈLE NARDI AND \\ NICOLE PAMBOUKDJIAN \\ Laboratoire de Microbiologie Laitière, Institut National de la Recherche Agronomique, CNRZ, \\ 78350 Jouy-en-Josas, France
}

(Received 8 August 1984 ; revised 13 November 1984)

The conditions under which Brevibacterium linens CNRZ 918, a strain isolated from the surface smear flora of Gruyère de Comté cheese, produced methanethiol from methionine were studied. Demethiolation was estimated from the methanethiol production capacity of resting cells. Methionine was demethiolated mainly during the exponential growth phase of the organism during which time the cells were rod-shaped and had a generation time of $5 \mathrm{~h}$, and the medium became alkaline. At the end of growth ( $\mathrm{pH} 9)$ the cells were coccoid, and produced only very little methanethiol. The production of methanethiol required the presence of methionine in the culture medium, this reflecting the probable induction of the enzyme systems involved. Glucose favoured growth and inhibited production of methanethiol. Lactate favoured both growth and methanethiol production.

Resting rod cells also produced methanethiol from structural analogues of methionine and from methionine-containing peptides. The apparent kinetic constants of the production of methanethiol for rod and coccoid cells were respectively $K_{\mathrm{m}}=14 \mathrm{mM}$ and $46 \mathrm{mM}, V_{\max }=$ $208 \mathrm{nkat}^{-1}$ and $25 \mathrm{nkat} \mathrm{g}^{-1}$. The optimum temperature and $\mathrm{pH}$ for production were $30^{\circ} \mathrm{C}$ and $\mathrm{pH} 8$. Azide or malonate favoured the production of methanethiol by resting cells, whereas chloramphenicol had no effect.

\section{INTRODUCTION}

Certain surface-ripened cheeses such as the French varieties Pont l'Evêque, Munster, Livarot, Vacherin and Camembert typically exhibit flavours variously described as 'cabbagey', 'garlic' or even 'putrid' (Adda et al., 1978; Hemme et al., 1982; Boyaval \& Desmazeaud, 1983). These flavours are attributable to sulphur compounds of varying complexity (Cuer et al., 1979c), which arise from the condensation of precursors either with or without the intervention of the enzyme systems of the microflora (Badings et al., 1975; Boelens et al., 1975; Cuer et al., 1979a, b; Forss, 1979). Methanethiol is found in all these cheeses, and always seems to arise by microbiological degradation of methionine (see Hemme et al., 1982).

Numerous micro-organisms can produce methanethiol from methionine (Kadota \& Ishida, 1972), including those commonly predominating in the microflora of cheeses (Richard \& Zadi, 1983) such as diverse species of Penicillium (Ruiz-Herrera \& Starkey, 1969a), yeasts (Schreier $e t$ al., 1976), Pseudomonas (Ito et al., 1976; Tanaka et al., 1977; Esaki et al., 1977; Laakso, 1979) and coryneform bacteria (Segal \& Starkey, 1969; Sharpe et al., 1976; Sharpe et al., 1977; Law \& Sharpe, 1978). Micro-organisms isolated from other sources such as soil and the rumen (Mitsuhashi \& Matsuo, 1950; Merricks \& Salsbury, 1975) as well as Clostridium sporogenes (Kreiss \& Hession, 1973) and Escherichia coli (Ohigashi et al., 1951) are also known to produce methanethiol from methionine.

Abbreviations: BM, basal medium; DTNB, 5,5'dithio-bis-2-nitrobenzoic acid; MTPC, methanethiol production capacity; sMTPC, specific methanethiol production capacity. 
The predominant surface rind flora of the orange-coloured smear-ripened cheeses such as Munster, Pont l'Evêque or Livarot is composed of strains related to Brevibacterium linens. This organism also forms a high proportion of the surface rind flora of other cheeses such as Gruyère de Comté and Beaufort (Accolas et al., 1978) or Camembert made from raw milk (Richard \& Zadi, 1983). Most of the strains of $B$. linens isolated from these three cheese types were able to produce methanethiol by demethiolation of methionine (D. Hemme \& J. Richard, unpublished results).

The present paper reports the effects of different conditions on the production of methanethiol from methionine by $B$. linens.

\section{METHODS}

Strain. Brevibacterium linens CNRZ 918 was obtained from the culture collection of the Centre National de Recherches Zootechniques (CNRZ). This strain was originally isolated in J. E. Auclair's laboratory by Accolas $e t$ al. (1978) from the surface rind flora of Gruyère de Comte cheese.

Media. The basal medium (BM) had the following composition $\left(\mathrm{g} \mathrm{l}^{-1}\right)$ : meat extract (Merck) $4 \cdot 0$, yeast extract (Difco) 3.0, bactotryptone (Difco) $10.0, \mathrm{KH}_{2} \mathrm{PO}_{4} 4 \cdot 0, \mathrm{NaOH}$ (pellets) $1 \cdot 0$. To this basal medium was added Lmethionine (Sigma) 1.0, D-glucose (Sigma) 5.0, or DL-sodium lactate (Sigma) $5 \cdot 0$. The pH of the media, initially between 7.4 and 7.6 , decreased by $0.2 \mathrm{pH}$ unit after autoclaving at $120^{\circ} \mathrm{C}$ for $20 \mathrm{~min}$.

Cultures. To ensure good reproducibility throughout the series of experiments, a stock of frozen cultures was constituted by inoculating (5\%) a series of tubes of $20 \mathrm{ml} \mathrm{BM}$, and without incubating, freezing them at $-20^{\circ} \mathrm{C}$. At the start of each experiment a frozen culture was thawed, transferred to a $100 \mathrm{ml}$ capacity Erlenmeyer flask and incubated at $26^{\circ} \mathrm{C}$ for $24 \mathrm{~h}$. This constituted the preculture which was then used to inoculate (1 to $\left.2 \%\right)$ the experimental culture. Experimental cultures were similarly grown in $1000 \mathrm{ml}$ capacity Erlenmeyer flasks filled to $20 \%$ capacity and shaken at 100 cycles $\mathrm{min}^{-1}$ in a water-bath reciprocal shaker.

At regular intervals, $5 \mathrm{ml}$ samples were taken to determine the morphology of the cells by phase-contrast microscopy, the $\mathrm{OD}_{650}$ (Beckman 25 spectrophotometer), the $\mathrm{pH}$ (Radiometer PM 63 using a combination electrode), and the capacity of the cells to produce methanethiol.

Methanethiol production capacity (MTPC) of harvested resting cells. Exponential-phase cells (culture $\mathrm{pH} 7.8$ to 8.2) and cells at the end of the exponential growth phase (culture $\mathrm{pH} \mathrm{9.0)}$ ) were harvested by centrifugation at $12500 \mathrm{~g}$ for $20 \mathrm{~min}$ at $4{ }^{\circ} \mathrm{C}$ (Sorvall). The cells were resuspended in $5 \mathrm{ml} 50 \mathrm{~mm}$-Tris/HCl buffer (Trizma, Sigma) at pH 8.0 and $4{ }^{\circ} \mathrm{C}$, and then washed twice and resuspended in the same buffer.

To measure MTPC, the reaction mixture $(1.50 \mathrm{ml})$ consisted of $1.25 \mathrm{ml}$ of cell suspension in the buffer $\left(\mathrm{OD}_{650}=\right.$ 0.8 , corresponding to $\left.0.48 \mathrm{mg} \mathrm{dry} \mathrm{wt} \mathrm{ml}^{-1}\right)$ to which was added $84 \mu \mathrm{l} 5 \mathrm{mM}$-DTNB $\left(5,5^{\prime}\right.$-dithio-bis-2-nitrobenzoic acid: Aldrich) dissolved in pure ethanol (final concn. $960 \mathrm{~mm}$ ) and $168 \mu \mathrm{l}$ of $134 \mathrm{~mm}$-substrate. The following substrates (all from Sigma) were used: L-methionine, L-methioninamide. $\mathrm{HCl}$, L-alanyl-L-methionine, Lmethionyl-L-alanine, L-ethionine, $\alpha$-keto- $\gamma$-methiolbutyric acid, $N$-formyl-DL-methionine, DL-methionine-Smethylsulphonium chloride, DL-methionine- $\alpha$-hydroxy analogue, and DL-methionine sulphoxide. Controls comprised the reaction mixture without cells, and the reaction mixture without substrates.

After a reaction time of $1 \mathrm{~h}$ at $30^{\circ} \mathrm{C}$, MTPC was estimated from the yellow colour (read at $412 \mathrm{~nm}$ against controls without substrates and without cells) produced by the reaction of DTNB with methanethiol liberated from the substrate. This reaction time was chosen as the methanethiol production was directly related to time incubation for up to $2 \mathrm{~h}$. The concentrations of methanethiol were determined from a linear standard graph obtained with solutions of known concentrations of ethanethiol between 6 and $60 \mu \mathrm{M}$. The specific methanethiol producing capacity (sMTPC) of the cells was defined as nmol methanethiol produced $\mathrm{s}^{-1}$ ( $\mathrm{g}$ dry wt of cells) $)^{-1}$ [nkat ( $\mathrm{g} \mathrm{dry} w \mathrm{t})^{-1}$ or nmol s $\mathrm{s}^{-1} \mathrm{~g}^{-1}$ ] from the substrate, under the conditions of assay.

Reproducibility. All results presented in this paper are the mean of three or more replicate assays. Variations observed were always less than $10 \%$.

\section{RESULTS}

Variation of the specific methanethiol producing capacity ( $(M T P C)$ of cells with growth phase. The growth of $B$. linens CNRZ 918 exhibited a lag phase of $30 \mathrm{~h}$. This was followed by a slow rate of exponential growth, accompanied by alkalinization of the medium, the $\mathrm{pH}$ reaching 9.0 and the $\mathrm{OD}_{650} 17.0$ at the end of growth (Fig. 1). The generation time in the basal medium (BM), either supplemented with $6.7 \mathrm{mM}$-methionine or not supplemented, was approximately $5 \mathrm{~h}$. Short rodshaped cells predominated in the culture until $48 \mathrm{~h}\left(\mathrm{OD}_{650} \simeq 4.0\right)$, after which coccoid forms appeared progressively, representing approximately $10 \%$ of the cells after $55 \mathrm{~h}$ incubation and $100 \%$ at the end of growth (Fig. 2). 


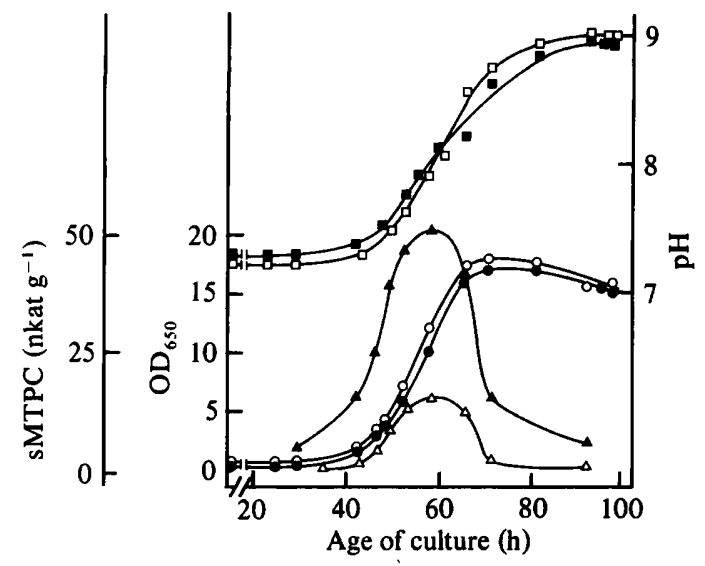

Fig. 1. Growth $(\mathrm{O}, \boldsymbol{O})$, changes in pH of the culture $(\square, \square)$ and sMTPC of harvested cells $(\triangle, \Delta)$ during growth of $B$. linens at $26^{\circ} \mathrm{C}$ in BM (open symbols) and in BM + methionine (filled symbols).

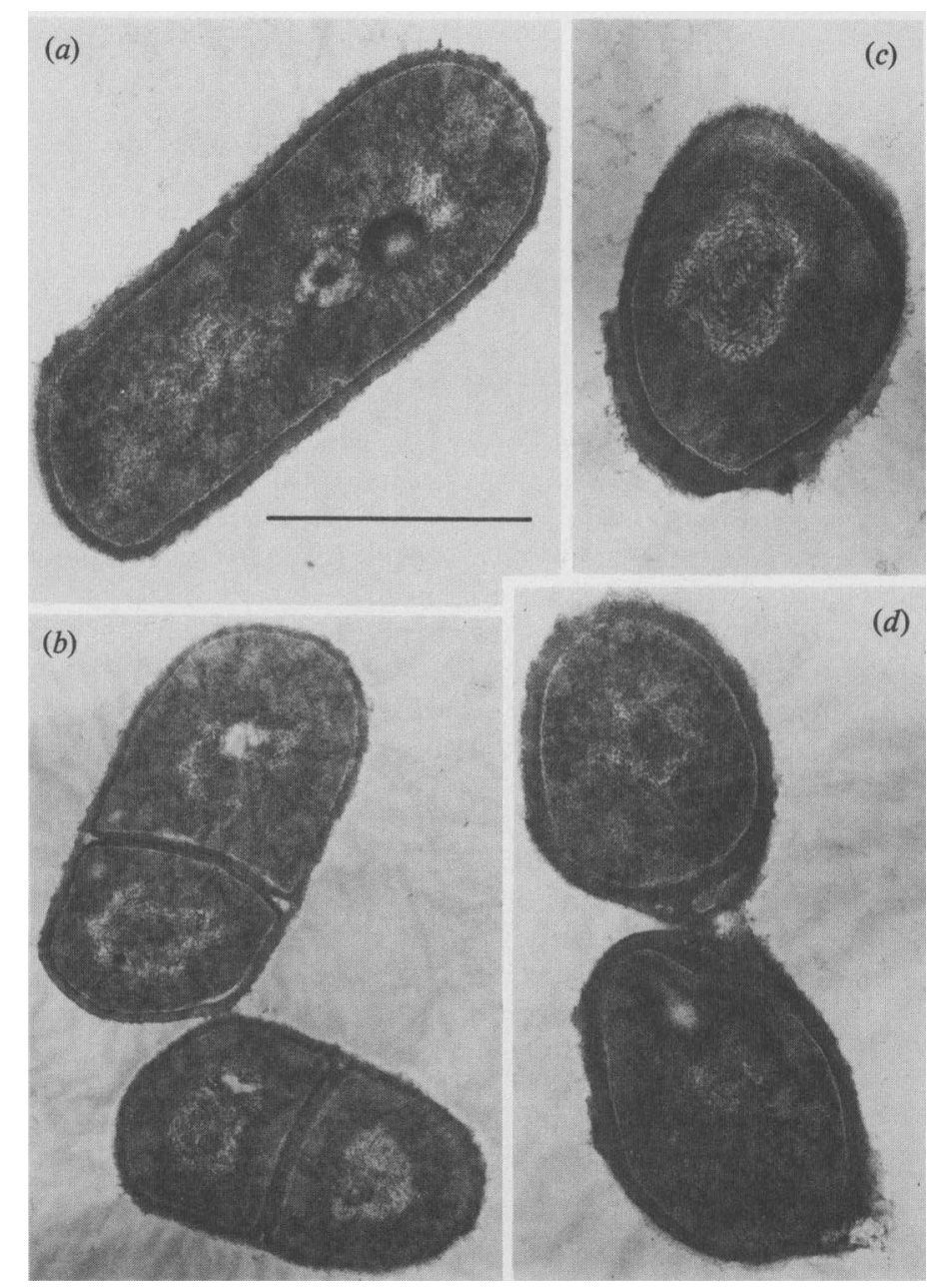

Fig. 2. Different morphological forms of $B$. linens CNRZ 918 obtained during growth in BM + methionine: (a) rod form at the beginning of division; (b) short rounded form (club form); (c) coccoid form; (d) diplococcoid form. The bar marker represents $500 \mathrm{~nm}$. 


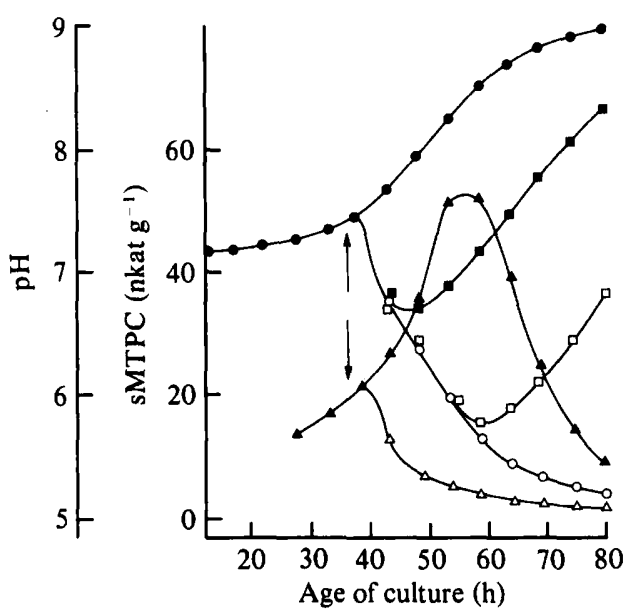

Fig. 3. Effect of the addition of glucose to the medium (BM + methionine) during growth at $26^{\circ} \mathrm{C}$ of $B$. linens CNRZ 918 on the $\mathrm{pH}$ of the culture $(O$, control without glucose; $\square, 0.5 \%$ glucose; $\square, 1 \%$ glucose; $O, 2 \%$ glucose) and on the sMTPC of the harvested cells ( $\triangle$, control without glucose; $\triangle, 1.0$ or $2.0 \%$ glucose). The arrows indicate the addition of glucose to the culture, $36 \mathrm{~h}$ after the start of the experiment.

The sMTPC of the cells increased during culture in BM + methionine to a maximum of $53 \mathrm{nkat}^{-1}$ obtained after $55 \mathrm{~h}$ incubation $\left(\mathrm{OD}_{650}=11.0 ; \mathrm{pH} \mathrm{8.0)}\right.$, and thereafter decreased progressively as coccoid forms became predominant. The sMTPC of the cells was more than three times greater in BM + methionine than in non-supplemented BM.

Influence of carbon source on the $s M T P C$. After $48 \mathrm{~h}$ growth, the $\mathrm{OD}_{650}$ in $\mathrm{BM}+$ methionine + lactate $(7 \cdot 2)$ was $80 \%$ greater than that in BM + methionine (4.0). But the sMTPC of the BM + methionine + lactate grown cells [44 nkat $\left.(\mathrm{g} \text { dry } w t)^{-1}\right]$ was only $10 \%$ greater than that of the $\mathrm{BM}+$ methionine grown cells [40 nkat $\left(\mathrm{g} \mathrm{dry} \mathrm{wt}^{-1}\right]$. In $\mathrm{BM}+$ methionine + glucose, the $\mathrm{OD}_{650}$ after $48 \mathrm{~h}(4.8)$ was $20 \%$ greater than that in BM + methionine, but the sMTPC of the cells [ 20 nkat $\left.\left(\mathrm{g}_{\text {dry }} \mathrm{wt}\right)^{-1}\right)$ ] was only half that of the BM + methionine grown cells.

However, when glucose was added ( 1 or $2 \%$ ) to BM + methionine after an initial $36 \mathrm{~h}$ growth period, the sMTPC dropped to $10 \%$ of that of cells in the control BM + methionine (Fig. 3). The addition of higher concentrations of glucose did not bring about a greater effect on the sMTPC.

When $0.5 \%$ glucose was present in the BM + methionine from the start, no acidification of the medium occurred. However, when glucose was added after $36 \mathrm{~h}$, the medium was initially acidified, the extent of the acidification increasing with increase in the concentration of glucose up to $1 \%$ (Fig. 3). The medium subsequently became alkaline at the same rate as the control cultures grown in BM + methionine, except at the level of $2 \%$ glucose. This irreversible effect of $2 \%$ glucose was accompanied by a substantial change in cell morphology, in particular thickening of the envelope and invaginations of the membrane (Fig. 4) which was not observed at lower concentrations of glucose nor in the presence of lactate.

Influence of cell concentration on the MTPC. For the coccoid forms, the MTPC increased with increasing cell concentration between 0.5 and $4.0 \mathrm{mg} \mathrm{dry} \mathrm{wt} \mathrm{of} \mathrm{cells} \mathrm{ml}^{-1}$ (Fig. 5). In contrast, the MTPC of the rod forms decreased at cell concentrations above $1.2 \mathrm{mg}^{\mathrm{dry} \mathrm{wt} \mathrm{ml}} \mathrm{m}^{-1}$.

Effect of storage of cells at $-20^{\circ} \mathrm{C}$ and $1{ }^{\circ} \mathrm{C}$ on SMTPC. Cells stored frozen at $-20^{\circ} \mathrm{C}$ for $45 \mathrm{~d}$ showed no loss of ability to produce methanethiol, irrespective of whether they were rod-shaped or coccoid. In contrast, both cell forms exhibited substantial loss of activity when held at $1{ }^{\circ} \mathrm{C}$ for $15 \mathrm{~d}(40 \%$ in the case of the rods, and $28 \%$ in the case of the coccoid forms). 


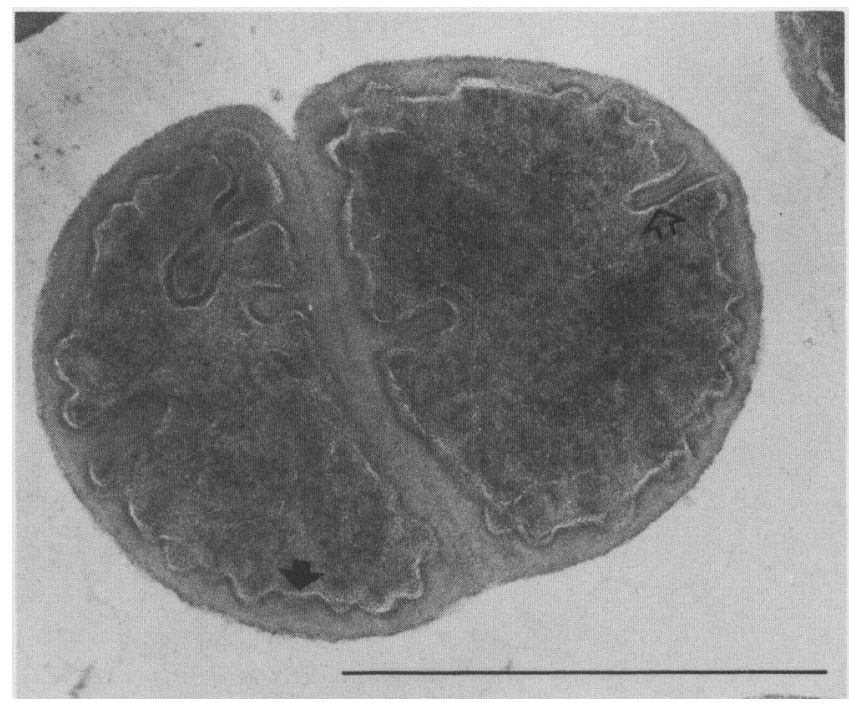

Fig. 4. Atypical form of $B$. linens CNRZ 918 obtained in cultures grown in BM + methionine supplemented with $2.0 \%$ glucose, showing invaginations of the membrane $(\Delta)$ and thickening of the envelope (-) The bar marker represents $500 \mathrm{~nm}$.

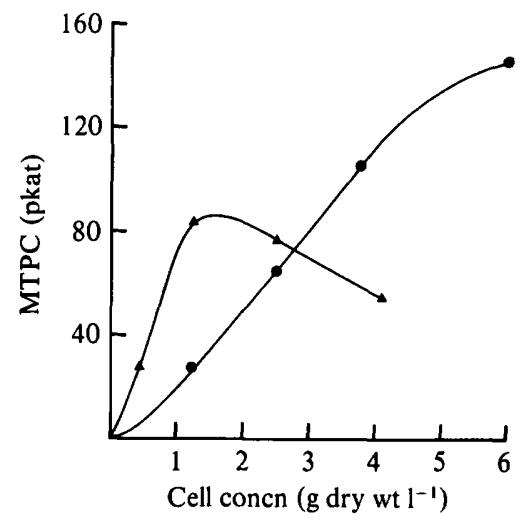

Fig. 5

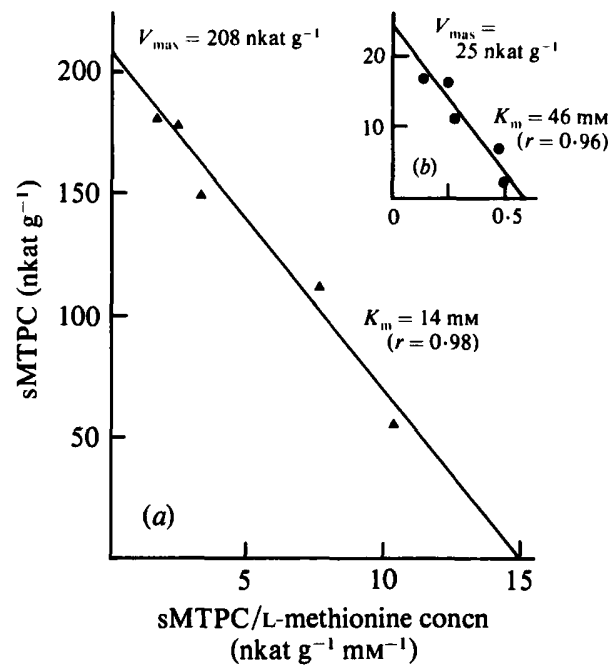

Fig. 6

Fig. 5. Effect of cell concentration on the MTPC of rod $(\Delta)$ and coccoid $(O)$ forms of $B$. linens CNRZ 918 measured with harvested cells.

Fig. 6. Influence of the L-methionine concentration on the SMTPC of $(a)$ rod and $(b)$ coccoid forms of resting cells of $B$. linens CNRZ 918 represented according to Woolf (1932). $r$, correlation coefficient.

Apparent affinity of the cells for methionine. The SMTPC of the harvested resting cells increased as the concentration of $L$-methionine in the assay mixture was increased. This occurred for both the rod and coccoid forms. However, while the saturating concentration of L-methionine was of the order of $100 \mathrm{~mm}$ for both forms, the apparent affinity exhibited by the rod forms (apparent $K_{\mathrm{m}}=14 \mathrm{mM}$ ) was three times as great as that exhibited by the coccoid forms (apparent $K_{\mathrm{m}}=$ $46 \mathrm{mM}$ ) (Fig. $6 a, b$ ). 
Table 1. Action of malonate and azide on the SMTPC of resting cells of Brevibacterium linens CNRZ 918

Rod cells were harvested after $55 \mathrm{~h}$ growth in BM + methionine and their sMTPC determined as described in Methods.

\begin{tabular}{|c|c|c|}
\hline \multicolumn{2}{|l|}{ Treatment } & $\begin{array}{c}\text { sMTPC } \\
(\% \text { of control })^{*}\end{array}$ \\
\hline \multicolumn{2}{|c|}{ Control (no inhibitor) } & $100(r=0.999)$ \\
\hline Sodium malonate & $\begin{array}{l}20 \mathrm{mM} \\
40 \mathrm{mM}\end{array}$ & $\begin{array}{l}240(r=0.998) \\
270(r=0.995)\end{array}$ \\
\hline Sodium azide & $\begin{array}{r}5 \mathrm{mM} \\
10 \mathrm{mM} \\
20 \mathrm{mM}\end{array}$ & $\begin{array}{l}320(r=0.992) \\
235(r=0.995) \\
225(r=0.989)\end{array}$ \\
\hline
\end{tabular}

\footnotetext{
* The correlation coefficients, $r$, were obtained for the regression line values of sMTPC at times varying between 0 and $240 \mathrm{~min}$.
}

Table 2. sMTPC of resting cells of Brevibacterium linens CNRZ 918 with respect to different substrates

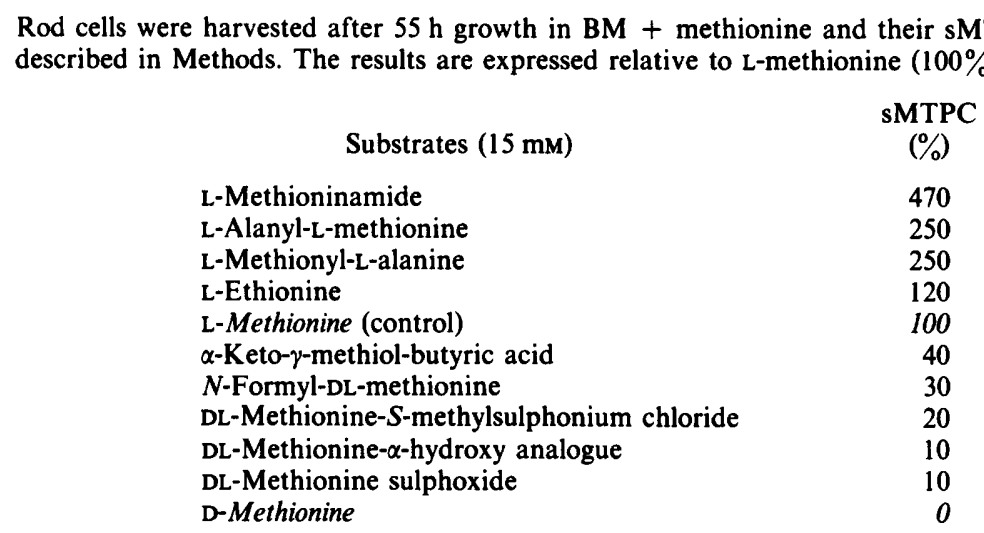

Effect of the $p H$ of the suspending buffer on the $S M T P C$. The maximum production of methanethiol by resting cells suspended in $50 \mathrm{mM}$-Tris/HCl buffer was obtained at $\mathrm{pH} 8.0$ in the case of both rod and coccoid forms. For the rod forms, the activity at pH 7.5 and at $\mathrm{pH} 8.5$ was approximately $25 \%$ of that obtained at the optimum. There is agreement between the fact that the sMTPC of resting cells is maximal at $\mathrm{pH} 8.0$ and the fact that the greatest sMTPC is obtained with cells harvested from cultures at $\mathrm{pH} 8 \cdot 0$.

Effect of temperature on the SMTPC. The optimum temperature for the production of methanethiol under the assay conditions was $30^{\circ} \mathrm{C}$ for the rod forms, and close to $35^{\circ} \mathrm{C}$ for the coccoid forms. These temperatures are higher than the optimum growth temperature of the strain $\left(26^{\circ} \mathrm{C}\right)$. When the strain was cultivated at a temperature higher than $30^{\circ} \mathrm{C}$, coccoid forms rapidly predominated in the culture, which consequently became less active with respect to production of methanethiol.

Action of metabolic inhibitors, chloramphenicol and structural analogues of methionine on the SMTPC. Sodium malonate and sodium azide both increased the sMTPC of the rod-shaped cells (Table 1); the lowest concentration of sodium azide used (5 mM) effected the greatest increase of the sMTPC.

Chloramphenicol $(150 \mu \mathrm{M})$ had no effect on the production of methanethiol when added to the buffered suspension of rod-shaped cells and incubated for up to $3 \mathrm{~h}$ at $30^{\circ} \mathrm{C}$.

Increases in SMTPC of resting rod cells were obtained when a number of structural analogues of methionine were used as substrates (Table 2). Taking the sMTPC obtained with L-methionine 
as substrate as $100 \%$, sMTPC values of $470 \%, 250 \%$ and $120 \%$ were obtained when Lmethioninamide, the peptides L-Ala-L-Met or L-Met-L-Ala, and L-ethionine, respectively, were used as substrate. D-Methionine, methionine sulphoxide, and the $\alpha$-hydroxy analogue of methionine had no or only a weak effect on the sMTPC.

\section{DISCUSSION}

The sMTPC observed with cells grown in the basal medium is probably the consequence of an induction of one or more enzyme(s) by the L-methionine present in the medium, that effect being reinforced when the medium is supplemented with L-methionine. Indeed, such an induction has been reported for Achromobacter (Ruiz-Herrera \& Starkey, 1970) and for the fungus Phomopsis viticola (Pezet \& Pont, 1980), but not for Pseudomonas fluorescens (Laakso, 1979), where the enzyme described was constitutive.

The decrease of sMTPC concomitant with the appearance of coccoid forms in the culture may be related to the usual morphological change of coryneform bacteria from rods to cocci, and could be in this case a direct consequence of a fall of the L-methionine (inducer) concentration.

The considerable decrease in the SMTPC of $B$. linens caused by addition of glucose to the BM + methionine medium was not observed with the lower fungi, where both L-methionine and glucose were simultaneously required for methanethiol production (Ruiz-Herrera \& Starkey, $1969 a, b$; Segal \& Starkey, 1969). This effect in $B$. linens may be due to a catabolite repression by glucose of one or more enzymes or transport proteins involved in methanethiol production, or to an inducer exclusion. Indeed glucose was a better growth substrate than L-methionine for $B$. linens CNRZ 918. This is perhaps related to the effect of glucose on the thickness of the cell envelopes, as reported by Mulder \& Antheunisse (1963).

The apparent kinetic constants determined for whole cells of $B$. linens CNRZ 918 are similar to those found for the demethiolating activity of crude cell-free extract of $B$. linens (D. Hemme, M. Nardi \& M. Ferchichi, unpublished data) and for the partially purified demethiolase of Pseudomonas ovalis (Esaki et al., 1977). The apparent $K_{\mathrm{m}}$ values of the cells of $B$. linens and of the crude cell-free extract are, however, seven times less than that reported for the reference demethiolase (EC 4.4.1.11) of Clostridium sporogenes (Kreis \& Hession, 1973).

The decrease in the MTPC with increasing cell concentration of the rod form of $B$. linens is a phenomenon almost identical to that reported for Pseudomonas fluorescens by Laakso \& Nurmikko (1976). These authors were not, however, able to explain the phenomenon. A reduction in oxygen concentration when high cell densities are used could be important. If so, the rod form is more sensitive than the coccoid form.

The decrease in SMTPC observed when the amino group of methionine is substituted may be tied to the requirement of the demethiolase for a pyridoxal phosphate coenzyme which in turn is dependent on the amino group. However, the higher activities obtained with peptides or Lmethioninamide probably reflect their easier entry into the cells (with the same or different systems), followed by their hydrolysis (by amidase for L-methioninamide or aminopeptidases for peptides) and consequently a higher intracellular concentration of L-methionine, as described for other species, e.g. Streptococcus lactis (Rice et al., 1978).

In contrast to what has been reported for $E$. coli (Ohigashi et al., 1951), Pseudomonas sp. (Miwatani et al., 1954), Aspergillus sp. (Ruiz-Herrera \& Starkey, 1969b) and Achromobacter starkeyi (Ruiz-Herrera \& Starkey, 1970), azide and malonate did not inhibit the sMTPC of $B$. linens CNRZ 918 but indeed increased it. As these compounds usually decrease the ATP concentration in the cell, it is possible that ATP inhibits the demethiolase(s), as has been reported for purified enzyme of Aspergillus sp. (Ruiz-Herrera \& Starkey, 1969b).

\footnotetext{
The authors extend their grateful thanks to J.-P. Accolas for providing the strain used in this study, to Micheline Rousseau and Christiane Le Gallo for the electron micrographs, to P. Labbe for his continued interest in the work, and to F. G. Martley for helpful criticism and assistance with the manuscript. One of the authors (M.F.) was supported by a bursary awarded by the Centre International des Etudiants Stagiaires, Paris.
} 


\section{REFERENCES}

Accolas, J.-P., Melcion, D. \& Vassal, L. (1978). Etude de la flore superficielle des fromages de Gruyère et de Beaufort. In XXth International Dairy Congress, Paris, pp. 773-774. Edited by Congrilait, Paris.

AdDA, J., Roger, S. \& Dumont, J.-P. (1978). Some recent advances in the knowledge of cheese flavor. In Flavor of Foods and Beverages, pp. 65-74. Edited by G. Charalambus \& G. E. Inglett. New York: Academic Press.

Badings, H. T., MaArse, H., Kleipool, R. J. C., Tas, A. C., Neeter, R. \& Noever, M. C. (1975). Formation of odorous compounds from hydrogen sulphide and methanethiol, and unsaturated carbonyls. In Proceedings of the International Symposium on Aroma Research, Zeist, pp. 63-73. Edited by $\mathrm{H}$. Maarse \& P. J. Groenen. Wageningen: Centre for Agricultural Publishing and Documentation.

BoElens, H., VAN DER LINDE, L. M., DE Valois, P. J., TAKKEN, H. J. \& VAN DORT, J. M. (1975). Organic sulphur compounds as flavour constituents: reaction products of carbonyl compounds, hydrogen sulphide and ammonia. In Proceedings of the International Symposium on Aroma Research, Zeist, pp. 95100. Edited by H. Maarse \& P. J. Groenen. Wageningen: Centre for Agricultural Publishing and Documentation.

Boyaval, P. \& Desmazeaud, M. J. (1983). Le point des connaissances sur Brevibacterium linens. Le Lait 63, 187-216.

Cuer, A., Dauphin, G., Kergomard, A., Dumont, J.-P. \& ADDA, J. (1979a). Production of $S$ methyl-thioacetate by Brevibacterium linens. Applied and Environmental Microbiology 38, 332-334.

Cuer, A., Dauphin, G., Kergomard, A., Dumont, J.-P. \& ADDA, J. (1979b). Production of $S$ methyl-thioacetate by Micrococcus cheese strains. Agricultural and Biological Chemistry 43, 1783-1784.

Cuer, A., Dauphin, G., Kergomard, A., Roger, S., DUMONT, J.-P. \& ADDA, J. (1979c). Flavour properties of some sulphur compounds isolated from cheeses. Lebensmittel Wissenschaft und Technologie 12, 258-261.

Esaki, N., Suzuki, T., Tanaka, H., Sada, K. \& RANDO, R. R. (1977). Deamination and $\gamma$-addition reactions of vinyl-glycine by $L$-methionine- $\gamma$-lyase. FEBS Letters 84, 309-312.

FoRSS, D. A. (1979). Mechanisms of formation of aroma compounds in milk and milk products. Journal of Dairy Research 46, 691-706.

Hemme, D., Bouillanne, C., Metro, F. \& DesmaZEAUD, M. J. (1982). Microbial catabolism of aminoacids during cheese ripening. Sciences des Aliments 2 , 113-123.

Ito, S., Nakamura, T. \& Eguchi, Y. (1976). Purification and characterization of methioninase from Pseudomonas putida. Journal of Biochemistry 79, 1263-1272.

KADOTA, H. \& IsHIDA, Y. (1972). Production of volatile sulfur compounds by microorganisms. Annual Review of Microbiology 26, 127-138.

Kreiss, W. \& Hession, C. (1973). Isolation and purification of L-methionine $\alpha$-deamino- $\gamma$-mercapto- methane-lyase (L-methioninase) from Clostridium sporogenes. Cancer Research 33, 1862-1865.

LAAKso, S. (1979). Evidence of multiple demethiolation of methionine by a methionine utilizing mutant of Pseudomonas fluorescens UK 1. FEMS Microbiology Letters 5, 407-409.

LAAKSO, S. \& NURMIKKo, V. (1976). A spectrophotometric assay for demethiolating activity. Analytical Biochemistry 72, 600-605.

LAW, B. A. \& Sharpe, M. E. (1978). Formation of methanethiol by bacteria isolated from raw milk and Cheddar cheese. Journal of Dairy Research 45, 267275.

MerRicks, D. L. \& Salsbury, R. L. (1975). Dethiomethylation of methionine by an extract of rumen protozoa: general substrate specificity. Journal of Animal Science 42, 955-959.

Mitsurashi, S. \& Matsuo, Y. (1950). Decomposition of thio-ether derivatives by bacteria. Japanese Journal of Experimental Medicine 20, 641-646.

Miwatani, T., OmUKaI, Y. \& Nakada, D. (1954). Enzymatic cleavage of methionine and homocysteine by bacteria. Medical Journal of Osaka University 5, 347-352.

Mulder, E. G. \& ANTHEunisse, J. (1963). Morphologie, physiologie et écologie des Arthrobacter. Annales de Microbiologie 105, 46-74.

Ohigashi, K., Tsunetoshi, A. \& Ichihara, K. (1951). The role of pyridoxal in methyl mercaptan formation, partial purification and resolution of methioninase. Medical Journal of Osaka University 2, 111117.

Pezet, R. \& Pont, V. (1980). Methanethiol, a morphogenetic factor produced from L-methionine by Phomopsis viticola Sacc. Canadian Journal of Microbiology 26, 356-362.

Rice, G., Stewart, F. H. C., Hillier, A. J. \& JaGo, G. R. (1978). The uptake of amino-acids and peptides by Streptococcus lactis. Journal of Dairy Research 45, 93-107.

RICHARD, J. \& ZADI, H. (1983). Inventaire de la flore bactérienne dominante des Camemberts fabriqués avec du lait cru. Le Lait 63, 25-42.

Ruiz-HerRera, J. \& Starkey, R. L. (1969a). Dissimilation of methionine by Fungi. Journal of Bacteriology 99, 544-551.

Ruiz-Herrera, J. \& Starkey, R. L. (1969b). Dissimilation of methionine by demethiolase of Aspergillus species. Journal of Bacteriology 99, 764-770.

Ruiz-Herrera, J. \& StaRkEy, R. L. (1970). Dissimilation of methionine by Achromobacter starkeyi. Journal of Bacteriology 104, 1286-1293.

Schreier, P., Drawert, F., Junker, A., Barton, H. \& LeUPOLD, G. (1976). Uber die Biosynthese von Aromastoffen durch Mikroorganismen. II. Bildung von Schwefelverbindungen aus Methionin durch Saccharomyces cerevisiae. Zeitschrift für LebensmittelUntersuchung und Forschung 162, 279-284.

Segal, W. \& Starkey, R. L. (1969). Bacterial decomposition of methionine and identity of resulting sulfur products. Journal of Bacteriology 98, 908913.

Sharpe, M. E., Law, B. A. \& Phillips, B. A. (1976). 
Coryneform bacteria producing methane-thiol. Journal of General Microbiology 94, 430-435.

Sharpe, M. E., Law, B. A., Phillips, B. A. \& Pitcher, D. G. (1977). Methanethiol production by coryneform bacteria: strains from dairy and human skin sources and Brevibacterium linens. Journal of General Microbiology 101, 345-349.
TANaka, H., Esaki, N. \& Soda, K. (1977). Properties of L-methionine- $\gamma$-lyase from Pseudomonas ovalis. Biochemistry 16, 100-106.

Woolf, B. (1932). In Allgemeine Chemie der Enzyme, p. 119. Edited by J. B. S. Haldane \& K. G. Stern. Dresden \& Leipzig: Steinkopff Verlag. 